\title{
KELOMPOK USAHA KACANG BAWANG DAN KACANG OVEN UNTUK MENINGKATKAN PEREKONOMIAN KELUARGA
}

\author{
S.P. Abrina Anggraini, Carmia Diahloka \\ Universitas Tribhuwana Tunggadewi Malang \\ e-mail : spabrina74@gmail.com
}

\begin{abstract}
ABSTRAK
Ipteks bagi Masyarakat (IbM) merupakan salah satu bentuk pengabdian masyarakat yang memiliki keunggulan tersendiri. Kali ini, tim pengusul mengambil lokasi pengabdian di daerah Kabupaten Malang pada UKM Kacang Bawang "GR" yang berlokasi di Kota Batu dan Kacang Oven "Tuin" yang berlokasi di Desa Ngijo Kecamatan Turen Kabupaten Malang. Adapun tujuan tim pengusul IbM ini adalah ingin mengembangkan produksi kacang bawang dan kacang oven di Kabupaten Malang yang bekerja sama dengan mitra untuk memperbaiki kualitas proses produksi dan pengemasan kacang bawang dan kacang oven tersebut dengan harapan daya jangkau pemasaran mitra semakin luas, sehingga pendapatan mitra akan bertambah dan dapat meningkatan ekonomi keluarga.

Rencana kegiatan yang akan dilakukan pada mitra adalah dengan memberikan pelatihan dan pendampingan dalam membuat desain kemasan agar lebih menarik dalam pemasaran dan cara menganalisa untung rugi UKM dalam bentuk analisa BEP usaha serta pemberian alat pengupas kulit ari kacang tanah, alat oven dan alat pengemas kacang bawang yang disesuaikan dengan kebutuhan mitra untuk mengembangkan usahanya sehingga produk yang dihasilkan akan lebih higienis saat proses pengupasan kulit ari dan tahan lebih lama dalam penyimpanan dengan menggunakan kemasan yang sesuai standar serta dapat dikemas lebih rapat dan rapi. Selain itu, tim pengusul juga memberikan trik-trik dalam teknik komunikasi pemasaran agar kegiatan pemasaran yang selama ini kurang efektif, akan semakin berkembang dengan adanya model pemasaran baru yang ditawarkan oleh tim pengusul yaitu pemasaran melalui media sosial (website) dan personal selling serta cara mendesain kemasan yang lebih menarik bagi konsumen. Sehingga kedua mitra ini dapat berkembang usahanya, dan perekonomian keluarga mereka menjadi baik, karena usaha kacang bawang dan kacang oven ini merupakan produksi rumahan yang berdaya jual tinggi
\end{abstract}

Kata kunci : Kacang Bawang, Kacang Oven, Pemasaran, alat pengupas kulit ari kacang

\begin{abstract}
Science and technology for society (IbM) is one form of community service that has its own advantages. This time, the team proposer takes place in the area of Malang devotion to UKM Beans Onions "Raihan" is located in Kota Batu and Nuts Oven "Tuin" located in the village Ngijo Turen District of Malang. The purpose of the team proposer IbM of this is to develop the production of beans onions and beans oven in Malang are working with partners to improve the quality of the production process and packing peanuts onions and beans oven with the hope of a range of partner marketing increasingly widespread, so that the partner revenue will increase and may increase the family income.

Plan activities to be carried out on a partner is to provide training and assistance in making the packaging design to make it more attractive in marketing and how to analyze the costbenefit of UKM in the form of analysis BEP business as well as the provision of peeler epidermis of peanuts, tools oven and appliance packaging peanuts onion tailored to the needs of partners to develop its business so that the resulting product will be more hygienic when the
\end{abstract}


process of stripping the epidermis and last longer in storage by using appropriate packaging standards and can packed more tightly and neatly.

In addition, the team proposer also provide the tricks in the techniques of marketing communication that marketing activities which have been less effective, will grow with the new marketing model offered by the team proposing that marketing through social media (website) and personal selling as well as how to design packaging more appealing to consumers. So that both partners can grow their business, and the economy of their families to be good, because the business onions and pea beans oven is a home production of highly selling

Keywords : Onions beans and peanuts oven, marketing, improve family economic

\section{PENDAHULUAN}

\subsection{Analisa Situasi Untuk Pengusaha Mikro}

Usaha kecil dan menengah dalam pembuatan kacang bawang "GR" yang berada di Desa Junrejo Kecamatan Junrejo Kota Wisata Batu, dengan akses jalan baik dan lancar dengan waktu tempuh kurang lebih 1 jam perjalanan serta bisa dikatakan sebagai industri rumah tangga (home industry). Sebagai pemilik usaha, Bapak Ririn Sutarto mempunyai tenaga kerja berjumlah 3 orang yang berasal dari penduduk sekitar yang terdiri dari 1 orang di bagian pengupasan, 1 orang di bagian pengemasan, dan 1 orang lagi di bagian penggorengan. Sedangkan untuk tenaga pemasaran dilakukan sendiri oleh Bapak Ririn Sutarto. Alasan mendirikan usaha kacang bawang ini selain untuk menambah pendapatan keluarga juga mempunyai tujuan yaitu mengembangkan usaha makanan kering atau camilan yang berbahan dasar dari kacang tanah tersebut.

Usaha kecil dan menengah lainnya adalah usaha pembuatan Kacang Oven "Tuin" yang berlokasi di Desa Sawahan Kecamatan Turen Kabupaten Malang, dengan akses jalan yang baik dan lancar dengan waktu tempuh kurang lebih 2,5 jam perjalanan. Sebagai pemilik usaha, Bapak Tuin mempunyai tenaga kerja 3 orang yang berasal dari penduduk sekitar yang terdiri dari 1 orang bagian pengolahan (bumbu) kacang tanah, 1 orang bagian pengovenan dan pengemasan, dan 1 orang lagi bagian pengiriman produk

\subsection{Kondisi Manajemen dan Investasi}

Manajemen usaha kacang bawang "GR" ini sebenarnya dikelola cukup baik, karena Bapak Ririn Sutarto sebagai pemilik usaha juga berperan sebagai manajer. Tetapi kondisi manajemen belum tertata dengan baik karena tidak adanya laporan keuangan, sehingga belum mampu membuat proyeksi keuangan apakah akan menguntungkan atau tidak. Sementara bahan baku berupa kacang tanah mudah dibeli di Kota Wisata Batu. Investasi meliputi : ruang tamu dengan ukuran $3 \times 4$ meter dan tempat proses pengemasan berukuran 2 x 3 meter serta dapur berukuran 2 x 3 meter untuk proses pengupasan dan penggorengan dan 1 (satu) buah kendaraan sepeda motor untuk pengangkut bahan dan pemasaran. Daerah pemasaran hanya meliputi daerah Malang Raya. Permintaan camilan kacang bawang selama ini belum semua terpenuhi, karena masih menggunakan tenaga manual, sehingga perbulannya hanya menghasilkan $120 \mathrm{~kg}$. Kebutuhan yang mendesak tidak dapat terpenuhi, karena kontinyuitas produksi tidak tercapai. Kondisi ini juga dialami oleh manajemen usaha kacang oven yang dikelola dengan sederhana, dimana Bapak Tuin sebagai pemilik usaha sekaligus berperan sebagai manajer. Pembagian kerja sebenarnya sudah 
berjalan, tetapi belum ada laporan keuangan secara tertulis dan terdokumentasi dengan baik. Sebenarnya Bapak Tuin sudah terbiasa mencatat laporan keuangannya meski sederhana. Laporan keuangan inilah yang dapat dijadikan dalam upaya pengelolaan keuangan yang baik sehingga bermanfaat bagi upaya merealisasikan pengembangan usaha. Selain itu mereka juga belum mampu membuat proyeksi keuangan untuk memastikan apakah pengembangan usaha akan menguntungkan atau tidak. Investasi meliputi : ruang tamu dengan ukuran $3 \times 4$ meter, dan tempat untuk proses pengemasan berukuran $2 \times 2$ meter, serta ruang dapur berukuran $3 \times 3$ meter untuk proses pengolahan dan pengovenan serta 1 buah kendaraan sepeda motor untuk pengangkut bahan dan pemasaran. Daerah pemasaran kacang oven ini hanya beredar di sebagian kota dan Kabupaten Malang. Menurut Bapak Tuin hal ini dikarenakan kurang luas daya pemasarannya, sehingga pendapatan yang diterima kurang maksimal. Teknik pemasaran yang ada saat ini kurang mendukung usaha kacang oven milik Bapak Tuin dikarenakan tidak adanya kemampuan beliau selaku manajer dalam bidang teknik komunikasi pemasaran.

\subsection{Kondisi Produksi}

Pada aspek produksi usaha kacang bawang mempunyai kapasitas produksi relatif kecil sekitar $10 \mathrm{~kg} /$ bulan, yang dikemas dengan berat bersih tiap bungkus adalah 20 gram, hal ini dikarenakan keterbatasan sarana yang digunakan yaitu saat proses pengupasan kulit ari kacang tanah secara manual, pengemasan menggunakan lilin untuk merekatkan kemasan dan tenaga kerja yang diperbantukan tidak banyak. Waktu yang dibutuhkan dalam proses produksi sekitar 5 jam $/ 1 \mathrm{~kg}$. Kondisi ini menyebabkan produksi kacang bawang hanya mampu mensuplai kebutuhan konsumen sebesar
$40 \%$ yaitu sekitar $10 \mathrm{~kg} /$ bulan dari permintaan pasar yang sebenarnya sekitar $300 \mathrm{~kg} /$ bulan. Sedangkan untuk kondisi produksi kacang oven yang dikemas dengan berat bersih $1 \mathrm{~kg}$ ini mempunyai kapasitas produksi sekitar $45 \mathrm{~kg} /$ bulan. Meski tidak perlu proses pengupasan kulit ari, karena langsung menggunakan kacang tanah yang sudah dikupas, namun waktu yang dibutuhkan dalam proses produksi sekitar 3 jam / $1 \mathrm{~kg}$ karena hanya mempunyai 1 buah alat oven. Kondisi dapur untuk proses penggorengan dan pengovenan juga kurang memadai sehingga tidak dapat merasa nyaman dalam pengerjaannya, hal ini langsung dirasakan oleh pekerja di kedua mitra tersebut yang cukup mengganggu dalam proses penggorengan dan pengovenan karena dapur yang sempit serta ruangan yang panas. Begitupun dengan proses pengemasan yang masih dengan cara manual mengakibatkan waktu yang digunakan banyak terbuang, karena selama ini untuk proses pengemasan kacang bawang masih menggunakan plastik kemasan yang direkatkan dengan lilin. Untuk pengemasan kacang oven sudah lebih modern dengan aluminium voil akan tetapi desain produk masih kurang menarik.

Kemasan memang memegang peranan penting dalam sebuah usaha, dengan kemasan yang menarik diharapkan omzet penjualan akan lebih meningkat. Disini dibutuhkan kreativitas untuk dapat menampilkan suatu kemasan yang menarik sehingga konsumen akan melirik produk anda dibanding produk lainnya. Diperlukan tenaga kerja lebih banyak jika menginginkan hasil produksi yang lebih banyak dari yang sebelumnya. Beberapa kelemahan yang dialami oleh kedua mitra tersebut adalah dalam hal teknik pengolahannya, karena tidak menggunakan bahan pengawet, sehingga produk kedua mitra ini tidak bisa bertahan lama dan hanya bertahan 2 minggu saja 


\section{METODE KEGIATAN}

Metode penyelesaian masalah yang akan dilaksanakan berdasarkan kesepakatan antara tim pelaksana IbM dengan kedua mitra UKM kacang bawang dan kacang oven adalah sebagai berikut :

- Pendidikan Masyarakat

Memberikan penyuluhan tentang teknik komunikasi sehingga dapat membantu dalam memperluas produksi pemasarannya. Memberikan pelatihan tentang analisa BEP untuk UKM supaya para UKM dapat mengetahui untung dan ruginya dalam berwirausaha. Memberikan pelatihan tentang SOP operasional alat pengupas kulit ari kacang, alat pengoven dan pengemas. Memberi penyuluhan dan pendampingan tentang cara mendesain kemasan yang menarik.

- Difusi Ipteks

Memberikan bantuan alat berupa rancangan alat pengemas dan alat pengupas kulit ari kacang pada UKM Kacang Bawang "GR" dan UKM Kacang Oven "Tuin"

- Pelatihan

Melakukan kegiatan pelatihan atau demo tentang pemakaian alat. Mengadakan pelatihan tentang perawatan pada alat.

\section{KARYA UTAMA}

Karya utama dalam kegiatan IbM ini adalah sebagai solusi dari permasalahan kedua mitra yaitu dengan memberikan bentuk teknologi tepat guna berupa alat penguat kulit ari kacang. Untuk dapat lebih meningkatkan kapasitas produksi kacang bawang, alat pengupas kulit ari kacang bagi industri rumah tangga yang bergerak dalam produksi kacang bawang sesuai kemampuan mereka, maka perlu dilakukan rancang bangun mesin pengupas kulit ari yang sesuai dengan kemampuan investasi dan biaya operasional industri rumah tangga tersebut (Warisno, 2004) dengan spesifikasi alat sebagai berikut yaitu dimensi 60x40x90 cm, kapasitas $10 \quad \mathrm{~kg} / \mathrm{jam}$, penggerak menggunakan dinamo $1 / 2 \mathrm{HP}$, material tabung terbuat dari stainless steel. Selain itu pemberian alat hand sealer dengan spesifikasi alat sebagai berikut : daya 500 $\mathrm{W}$, panjang $400 \mathrm{~mm}$, lebar $3 \mathrm{~mm}$, waktu pemanasan 0,2 s/d 1,5 (s), ketebalan 0,5 $\mathrm{mm}$. Berdasarkan data hasil pengabdian masyarakat ini, maka perlu adanya teknologi untuk membantu peningkatan potensi UKM kacang bawang kedua mitra. Data hasil analisa serta hasil perubahan setelah kegiatan IbM tersebut adalah sebagai berikut

Tabel 1. Hasil perkembangan antara sebelum dan sesudah IbM.

\begin{tabular}{|c|c|c|c|c|c|}
\hline \multirow[t]{2}{*}{ No } & \multirow[t]{2}{*}{ Kegiatan } & \multicolumn{2}{|c|}{ Kacang Bawang GR } & \multicolumn{2}{|c|}{ Kacang Oven TUIN } \\
\hline & & Sebelum IbM & Sesudah IbM & Sebelum & Sesudah IbM \\
\hline 1 & Daya simpan & 2 minggu & 3 minggu & 2 minggu & 1 bulan \\
\hline 2 & $\begin{array}{l}\text { Kapasitas } \\
\text { produksi }\end{array}$ & $10 \mathrm{~kg}$ & $14 \mathrm{~kg}$ & $45 \mathrm{~kg}$ & $60 \mathrm{~kg}$ \\
\hline 3 & Omzet & Rp 5.600.000,- & Rp 7.337.000,- & Rp 1.800.000,- & $\operatorname{Rp} 2.142 .900,-$ \\
\hline 4 & $\begin{array}{l}\text { Luas } \\
\text { Pemasaran }\end{array}$ & $\begin{array}{l}\text { 1. Malang } \\
\text { Raya (Kota } \\
\text { Malang, Kab. } \\
\text { Malang dan } \\
\text { Kota Batu) }\end{array}$ & $\begin{array}{l}\text { 1. Malang Raya } \\
\text { 2. Denpasar } \\
\text { 3. Surabaya } \\
\text { 4. Sidoarjo } \\
\text { 5. Bogor }\end{array}$ & 1. Turen & $\begin{array}{l}\text { 1. Turen } \\
\text { 2. Gondanglegi } \\
\text { 3. Kepanjen } \\
\text { 4. Tajinan }\end{array}$ \\
\hline
\end{tabular}




\section{ULASAN KARYA}

Keunggulan dari teknologi alat pengupas kulit ari kacang ini adalah sebagai alat untuk mengupas kulit ari pada kacang yang bermanfaat sebagai alat bantu para UKM kacang bawang dalam proses pengupasan kulit ari sehingga waktu pemrosesan akan lebih cepat efektif dan efisien (Drs. Haryoto, 1995). Hasil yang didapat pun akan lebih banyak dan lebih cepat dihasilkan sehingga dapat memenuhi pemesanan lebih banyak dan memenuhi permintaan konsumen lebih banyak dari biasanya. Alat roll oven untuk mitra usaha kacang oven juga banyak memberikan waktu proses yang lebih efektif dan efisien sehingga tdak perlu lagi mengeluarkan biaya untuk sewa alat oven. Pelatihan tentang teknik komunikasi pemasaran banyak memberikan pengetahuan tentang cara melakukan promosi usaha dagangnya sehingga akan membantu memperluas daerah pemasaran. Selain itu dengan pemberian mesin oven untuk UKM Kacang Oven akan meningkatkan produksi kacang oven sehingga dapat memenuhi permintaan pasar. Memberikan metode cara menganalisa BEP dalam menjalankan usahanya sangat banyak membantu dalam hal penjualan produk sehingga kedua mitra mengetahui titik impas dimana usaha mereka tidak mengalami untung atau pun rugi, sehingga mereka mengetahui batas mulai mengetahui banyaknya keuntungan yang diperoleh dalam bentuk rupiah maupun unit. Selain itu dengan pemberian pelatihan cara komunikasi pemasaran yang baik akan membantu mendorongnya proses pemasaran yang semakin luas dengan menggunakan teknik komunikasi pemasaran sehingga pelanggan atau konsumen akan lebih tertarik untuk membeli dengan cara mereka memberikan promosi produknya. Dengan memberikan bahasa dagang merupakan trik untuk menarik minat konsumen supaya ingin membeli lebih banyak dan ditambah lagi dengan cara bentuk kemasan yang menarik sehingga peminat para konsumen semakin besar untuk lebih banyak memesan dari biasanya. Beberapa teknologi yang telah diberikan berupa alat dan pendidikan pelatihan, memberikan tambahan pendapatan ekonomi mereka dalam menjalankan usaha, dimana yang kita tahu bahwa persaingannya dalam usaha kripik tempe sangatlah ketat.

Karya yang telah dihasilkan dari kegiatan IbM ini telah sesuai dengan perkembangan dan kebutuhan masyarakat UKM kacang bawang dan UKM kacang oven. Karya yang telah dibuat telah memiliki nilai penting untuk perkembangan usaha kacang dari kedua mitra "GR" dan "Tuin" dengan adanya peningkatan omzet dari kedua UKM kacang serta peningkatan kapasitas produksi.

\section{DAMPAK DAN MANFAAT KEGIATAN}

\section{Dampak}

Pada kegiatan program IbM ini dampaknya adalah kedua mitra UKM kacang bawang adalah pada daya simpan kacang bawang lebih lama karena menggunakan alat pengupas kulit ari sehingga lebih higienis dan kadar airnya berkurang banyak (Drs. Haryoto, 2009) sehingga lebih bertahan lebih lama dari 2 minggu menjadi 1 minggu. Untuk UKM kacang oven memiliki daya simpan lebih lama dari sebelumnya yaitu 2 minggu menjadi 1 bulan karena dengan bantuan alat roll oven yang lebih maksimal kerjanya maka proses pengeringannya lebih baik dari sebelumnya yang hanya mengandalkan oven yang lebih kecil kapasitasnya dan daya panasnya kurang maksimal sehingga proses penge-ringannya pun tidak maksimal dan lebih sering menyewa alat roll oven 
ditempat lain. Kapasitas produksi UKM kacang bawang yang semakin meningkat dari $10 \mathrm{~kg}$ menjadi $14 \mathrm{~kg}$ sedangkan UKM kacang oven juga semakin meningkat dari $45 \mathrm{~kg}$ sampai $60 \mathrm{~kg}$. Omzet penghasilan UKM kacang bawang yang mereka peroleh semakin meningkat dan $\mathrm{Rp}$ 5.600.000,/bln menjadi Rp 7.337.000,-/bln sedangkan pada UKM kacang oven meningkat pula dari $\mathrm{Rp} \quad 1.800 .000,-/ \mathrm{bln}$ menjadi $\mathrm{Rp}$ 2.142.900,-/bln. Luas pemasaran mengalami peningkatan dari UKM kacang oven yang semula hanya sekitar malang raya maka sekarang sudah sampai ke 6 kota sedangkan UKM kacang oven juga semakin meningkat yang semula sekitar Turen saja maka sekarang sudah mencapai 4 daerah.

Pelatihan yang telah diperoleh untuk kedua mitra tersebut berdampak semakin menambah pengetahuan tentang bagaimana mengetahui bahwa usaha mereka akan mengalami keuntungan atau kerugian serta mengetahui besarnya target untuk mencari keuntungan yang akan mereka dapatkan berupa rupiah atau pun unit. Sehingga akan mengetahui berapa kapasitas yang akan mereka tambahkan sesuai dengan target penjualan. Jadi tidaka akan mengalami kerugian dalam melakukan usaha karena dapat menganalisa BEP yang akan menguntunkan mereka dalam memperoleh keuntungan atau laba usaha.

\section{Manfaat}

Adanya tambahan alat pengupas kulit ari yang baru maka dapat memenuhi permintaan pasar yang kadang-kadang mendesak dan permintaan yang banyak dari konsumen yang biasanya permintaan yang secara tiba-tiba ingin dipenuhi. Selain lama daya simpan yang dikarenakan sebelumnya hanya dikupas secara manual akan memperluas jangkauan pemasaran dan disertai dengan lebih memahaminya trik dalam komunikasi pemasaran yang bermanfaat bagi para usaha kacang bawang dan kacang oven untuk cara mempromosikan dagangan usahanya sehingga akan menambahkan jumlah pelanggan atau konsumen untuk memenuhi permintaan kacang bawang dan kacang oven. Selain itu bentuk kemasan yang lebih menarik bagi konsumen untuk memesan produk usahanya. Manfaat lebih dirasakan adalah peningkatan omzet yang lebih besar 2 dari biasanya. Hal inilah yang paling mereka syukuri dengan adanya penambahan alat bantu dalam peningkatan usaha dengan dilengkapi dengan cara perawatan dan penggunaan alat yang benar sehingga lebih awet dalam penggunaannya. Manfaat yang lain yaitu semakin menambah pengetahuan dan pemahaman dengan adanya teknologi baru berupa alat pengupas kulit ari kacang dan alat roll ovel serta memahami bagaimana trik cara komunikasi pemasaran dari ilmu berwirausaha dan memahami cara menganalisis BEP dengan mudah dan cermat.

\section{KESIMPULAN}

1. Daya simpan ada peningkatan:

a. UKM Kacang Bawang GR : dari 2 minggu menjadi 3 minggu

b. UKM Kacang Oven Tuin : dari 2 minggu menjadi 1 bulan

2. Kapasitas produksi ada peningkatan :

a. UKM Kacang Bawang GR : 10 $\mathrm{kg}$ / bulan menjadi $14 \mathrm{~kg}$ / bulan

b. UKM Kacang Oven Tuin : $45 \mathrm{~kg}$ bulan menjadi $60 \mathrm{~kg}$ / bulan

3. Omzet per bulan ada peningkatan :

a. UKM Kacang Bawang GR : $31 \%$ dari Rp 5.600.000,- menjadi Rp 7.337.000

b. UKM Kacang Oven Tuin : 19\% dari Rp 1.800.000,- menjadi Rp 2.142.900,-

4. Daerah pemasaran ada peningkatan :

a. UKM Kacang Bawang GR : Malang Raya menjadi Malang 
Raya, Surabaya, Sidoarjo, Denpasar, Bogor dan Jakarta

b. UKM Kacang Oven Tuin : Turen menjadi Turen, Gondanglegi, Tajinan dan Kepanjen

5. Pengetahuan semakin bertambah dengan adanya alat pengiris tempe dan alat pengemas

6. Pengetahuan semakin bertambah dengan adanya aplikasi analisa BEP dalam mengetahui untung rugi usaha

7. Pemahaman semakin meningkat dengan adanya teknik komunikasi pemasaran dalam usaha keripik tempe

\section{DAFTAR PUSTAKA}

1. Warisno, 2004. Membuat Aneka Olahan Kacang Tanah. Jakarta, Agromedia Pustaka

2. Drs. Haryoto, 1995. Teknologi Tepat Guna PENGUPAS KACANG TANAH. Yogyakarta, Kanisius

3. Drs. Haryoto, 2009. Membuat Aneka Olahan Kacang Tanah. Yogyakarta, Kanisius 